University of Nebraska - Lincoln

DigitalCommons@University of Nebraska - Lincoln

2013

High-impact animal health research conducted at the USDA's

National Animal Disease Center

\author{
J. P. Bannantine \\ Steven C. Olsen \\ Marcus E. Kehrli Jr. \\ Thad B. Stanton \\ Eduardo Casas
}

See next page for additional authors

Follow this and additional works at: https://digitalcommons.unl.edu/usdaarsfacpub

Part of the Agriculture Commons

This Article is brought to you for free and open access by the U.S. Department of Agriculture: Agricultural Research Service, Lincoln, Nebraska at DigitalCommons@University of Nebraska - Lincoln. It has been accepted for inclusion in Publications from USDA-ARS / UNL Faculty by an authorized administrator of DigitalCommons@University of Nebraska - Lincoln. 


\section{Authors}

J. P. Bannantine, Steven C. Olsen, Marcus E. Kehrli Jr., Thad B. Stanton, Eduardo Casas, Diana L. Whipple, and Kurt A. Zuelke 
Review

\title{
High-impact animal health research conducted at the USDA's National Animal Disease Center
}

\author{
John P. Bannantine*, Steven C. Olsen, Marcus E. Kehrli Jr., Thad B. Stanton, \\ Eduardo Casas, Diana L. Whipple, Kurt A. Zuelke
}

U.S. Department of Agriculture, Agricultural Research Service, National Animal Disease Center, Ames, IA, USA

\section{A R T I C L E I N F O}

\section{Article history:}

Received 5 October 2012

Accepted 5 April 2013

\section{Keywords:}

Animal health

Zoonosis

Research facility

\begin{abstract}
A B S T R A C T
Commissioned by President Dwight Eisenhower in 1958 and opened with a dedication ceremony in December 1961, the USDA, Agricultural Research Service (ARS), National Animal Disease Center (NADC) celebrated its 50-year anniversary in November 2011. Over these 50 years, the NADC established itself among the world's premier animal health research centers. Its historic mission has been to conduct basic and applied research on selected endemic diseases of economic importance to the U.S. livestock and poultry industries. Research from NADC has impacted control or management efforts on nearly every major animal disease in the United States since 1961. For example, diagnostic tests and vaccines developed by NADC scientists to detect and prevent hog cholera were integral in the ultimate eradication of this costly swine disease from the U.S. Most major veterinary vaccines for critical diseases such as brucellosis and leptospirosis in cattle, porcine respiratory and reproductive syndrome (PRRS), porcine parvovirus and influenza in swine had their research origins or were developed and tested at the NADC. Additional discoveries made by NADC scientists have also resulted in the development of a nutritional approach and feed additives to prevent milk fever in transition dairy cattle. More recently, NADC's archive of historic swine influenza viruses combined with an established critical mass of influenza research expertise enabled NADC researchers to lead an effective national research response to the pandemic associated with the novel 2009 H1N1 influenza virus. This review commemorates some of the key animal health contributions in NADC's first 50 years, recaps the newly completed modernization of the center into new facilities, and offers highlights of the ongoing research that will define NADC's mission going forward.
\end{abstract}

\section{Contents}

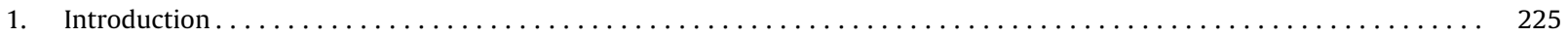

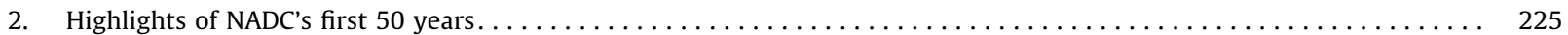

3. Swine viral diseases caused by classical swine fever virus, porcine parvovirus, hemagglutinating encephalomyelitis virus

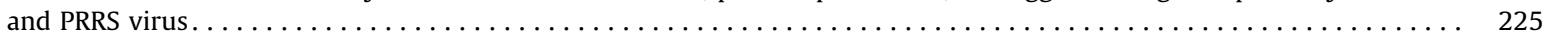

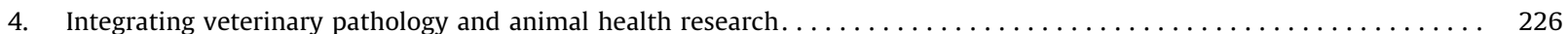

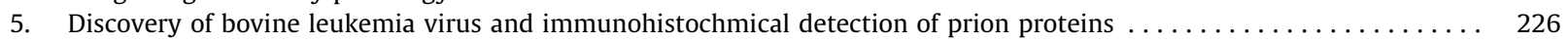

\footnotetext{
* Corresponding author at: National Animal Disease Center, USDA-Agricultural Research Service, 1920 North Dayton Avenue, Ames, IA 50010, USA. Tel.: +1 515337 7340; fax: +515 3377428 .

E-mail address: john.bannantine@ars.usda.gov (J.P. Bannantine).
} 


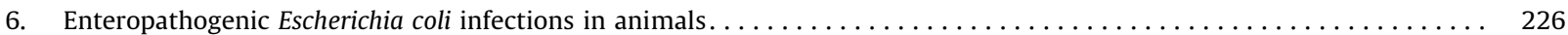

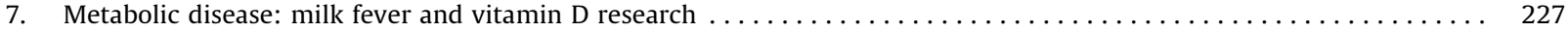

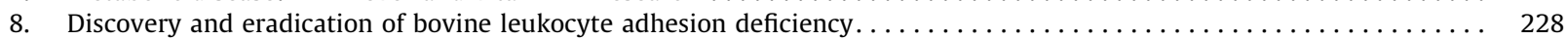

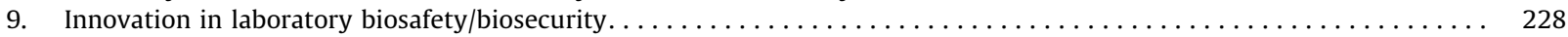

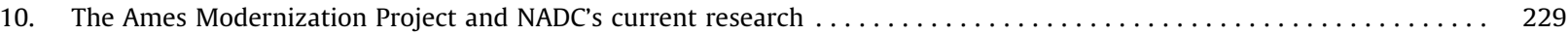

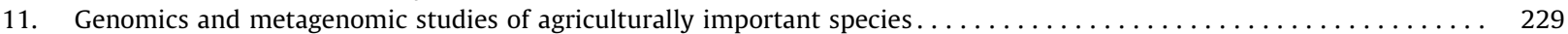

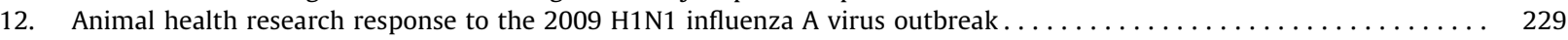

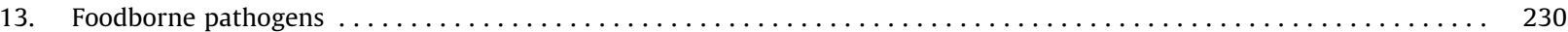

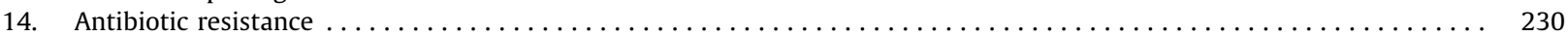

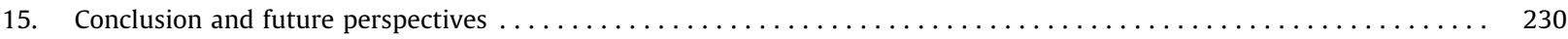

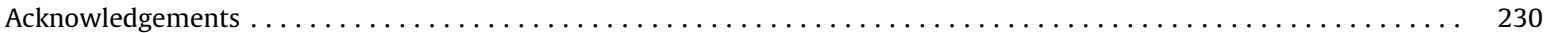

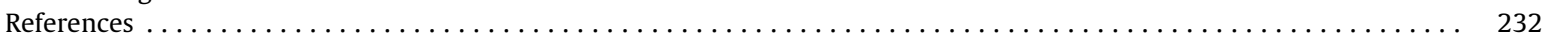

\section{Introduction}

The National Animal Disease Center (NADC) was established in Ames, Iowa in 1961, following a nation-wide search and selection process to identify a suitable location. Key factors that ultimately drove the selection of Ames for the new USDA research center were its close proximity and programmatic alignment with the Iowa State University College of Veterinary Medicine, a central location within the nation's major livestock producing region, and availability of an attractively-priced parcel of land suitable for constructing the new facility. At the time, the NADC represented the state-of-the-art in design and construction of high-containment animal health research facilities. Indeed, the original facilities served the center and the nation well in supporting research on some of the most infectious livestock diseases of the era. As a historical note of interest, these original facilities were decommissioned in 2011 after NADC staff moved into new state-of-the-art laboratories and administrative facilities at the same Ames location.

Since its inception, the NADC has combined a unique blend of multi-disciplinary technical and scientific expertise with state-of-the-art facilities and infrastructure to investigate the country's most significant animal health problems. NADC researchers specialize in performing high-level biocontainment research (BSL-2 and BSL-3 levels), involving infectious and potentially zoonotic disease challenge studies in cattle, swine, sheep and poultry. To respond to a growing national concern that traditional zoonotic diseases such as tuberculosis, brucellosis, or emerging diseases such as chronic wasting disease can become established in wildlife reservoirs and then re-emerge in livestock or humans, NADC has established the scientific and animal handling expertise to incorporate elk, bison, feral swine, white-tailed deer and other cervids, and a range of other species into routine disease pathogenesis, transmission and vaccinology research. Indeed, NADC's new high biocontainment facilities were designed with unique penning and gating systems required to support infectious disease research in these wildlife and livestock species.

Many of the infectious diseases of livestock that were present back in 1961 remain as significant disease threats today (e.g. leptospirosis, brucellosis, Johne's disease, and others (Hartskeerl et al., 2011; Kennedy, 2011; Pappas, 2010). With global mobility of people and animals at higher levels than ever before, the speed and potential for both 'historic' and newly emerging infectious diseases to significantly impact both animal and human health is everincreasing. Today, as throughout its history, the challenge for NADC is to keep the country one step ahead of current and emerging disease threats in livestock through research. This review will showcase research that enabled NADC to meet this challenge during its first 50 years, and will highlight the capabilities of its modernized facilities, which along with the strategic application of basic science, promises to define its mission going forward.

\section{Highlights of NADC's first 50 years}

Initially named National Animal Disease Laboratory (NADL), construction of the facilities began in 1958 in Ames, Iowa (Fig. 1). All USDA animal health-related research at that time was conducted at facilities in Beltsville, Maryland, and it was a major undertaking to move established animal colonies, dedicated to existing research projects, to Ames. With these logistical obstacles overcome, the first scientific experiments began in 1961 at the same time the first director, William A. Hagen, was hired. The new facilities were dedicated on June 27, 1961 and the diseases to be studied included hog cholera, tuberculosis, brucellosis, vibriosis, mastitis, leptospirosis, vesicular stomatitis virus, swine erysipelas and bovine shipping fever. The first two research articles stemming from research conducted at the new NADL were published by October of the same year, one reporting the presence of Leptospira on a Pennsylvania farm (Clark et al., 1961) and the second examining culture conditions for the swine pathogen Erysipelothrix rhusiopathiae (White and Shuman, 1961). One particularly noteworthy achievement, among several major research accomplishments from NADC's initial years, was the development of an economically feasible and rapid diagnostic test that enabled eradication of hog cholera and the concurrent establishment of NADC's world-class team of swine virology researchers.

\section{Swine viral diseases caused by classical swine fever virus, porcine parvovirus, hemagglutinating encephalomyelitis virus and PRRS virus}

In the 1800s and first half of the 1900s, outbreaks of hog cholera swept over the countryside, and the causative agent, classical swine fever virus, was considered endemic across the United States. Hog cholera caused losses that 


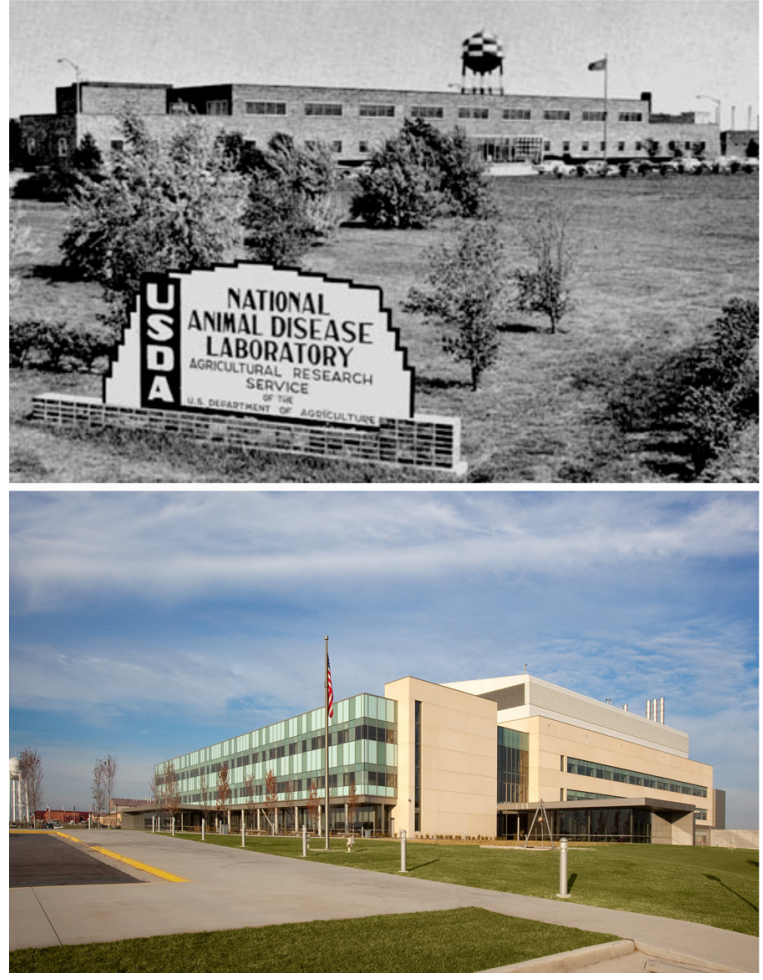

Fig. 1. NADC facilities located in Ames, Iowa when it first opened in 1961 (A) and today (B).

devastated the hog farming industry at the time and still cost swine producers $\$ 50$ million a year by the 1960 s (U.S. Department of Agriculture, 1978). In 1963, NADC scientist Dr. William Mengeling and coworkers developed a rapid immunofluorescent antibody test that took less than a day to diagnose classical swine fever virus infection (Mengeling et al., 1963). No other economically feasible diagnostic test was available at the time, and no equal or better test has since been developed. This rapid test enabled one of the greatest accomplishments in NADC's history, the eradication of hog cholera in the United States by 1978.

Dr. Mengeling (Fig. 2) and his colleagues later applied their expertise in viral diseases of swine to make significant advancements in vaccine development for PRRS (Mengeling et al., 1999a,b,c) and porcine parvovirus (Mengeling et al., 1979; Paul and Mengeling, 1984, 1986). He was the first to isolate porcine parvovirus (Mengeling, 1972) and to definitively establish, under both field and laboratory conditions, its role in maternal reproductive failure of swine. Prior to the availability of an effective vaccine, porcine parvovirus-induced reproductive failure was estimated to cost the swine industry between $\$ 25$ and $\$ 75$ million annually. A strain of porcine parvovirus (NADL 2) isolated and characterized at NADC was used to develop both inactivated and attenuated vaccines for porcine parvovirus-induced reproductive failure. All commercially available vaccines on the market today contain the NADL 2 strain of virus, and their production and testing was patterned after the procedures described at the NADC. Millions of vaccine doses have been distributed and used since it was first licensed.

\section{Integrating veterinary pathology and animal health research}

The close partnership between the Iowa State University College of Veterinary Medicine and NADC has fostered the professional development of numerous veterinary pathologists, and the integration of veterinary pathology into most of NADC's research programs. A number of NADC's scientists, including Drs. Lawrence H. Arp, Norman F. Cheville, Randall C. Cutlip, Janice M. Miller, and Harley W. Moon, have been board certified veterinary pathologists who went on to make significant contributions to the basic understanding of pathophysiological mechanisms underlying various diseases. For example, Dr. Cheville is internationally known for his work in characterizing ultrastructural changes in disease and for his seminal book on the topic (Cheville, 2009). Dr. Arp's greatest contributions were in describing pathophysiology and lesions of various diseases in turkeys. Dr. Cutlip made contributions in the areas of transmissible spongiform encephalopathies (TSEs), adenovirus, pasturellosis, ovine progressive pneumonia, and other respiratory pathogens. Contributions by Drs. Miller and Moon are particularly noteworthy and are summarized in the next two sections.

\section{Discovery of bovine leukemia virus and immunohistochmical detection of prion proteins}

Dr. Janice M. Miller (Fig. 2) began her career at NADC in 1968 working as a pathologist on bovine leukemia virus (BLV). She not only discovered BLV (Miller et al., 1969), but also developed an antibody test, targeting a glycoprotein to detect the virus (Miller and Van Der Maaten, 1977). During her career, she also worked on bovine herpesvirus (Miller et al., 1991), bovine immunodeficiency-like virus (Whetstone et al., 1991), bovine tuberculosis (Miller et al., 2002), and other major cattle diseases, greatly reducing their threat to U.S. livestock production and exports. She finished her career working in transmissible spongiform encephalopathies (TSEs) including transmissible mink encephalopathy in cattle, chronic wasting disease in cervids and scrapie in sheep. She developed immunohistochemical (IHC) techniques for detection of the prion protein in brain tissue of sheep with scrapie (Miller et al., 1993). This IHC test was subsequently applied globally to TSEs that affect other animal species, and continues to serve as a definitive diagnostic test for TSEs to this day. Dr. Miller (NADC's first female veterinarian researcher) had a highly distinguished career that culminated in her becoming a member of both the US National Academy of Sciences and the ARS Hall of Fame. However, despite her considerable professional achievements, she would frequently and humbly quote, "I'm a jack of all trades, but master of none."

\section{Enteropathogenic Escherichia coli infections in animals}

Dr. Harley Moon's research team at the NADC examined the interactions between diarrheagenic E. coli and animal intestinal tissues at the molecular, cellular and tissue levels, employing state-of-the-art technologies as they became 

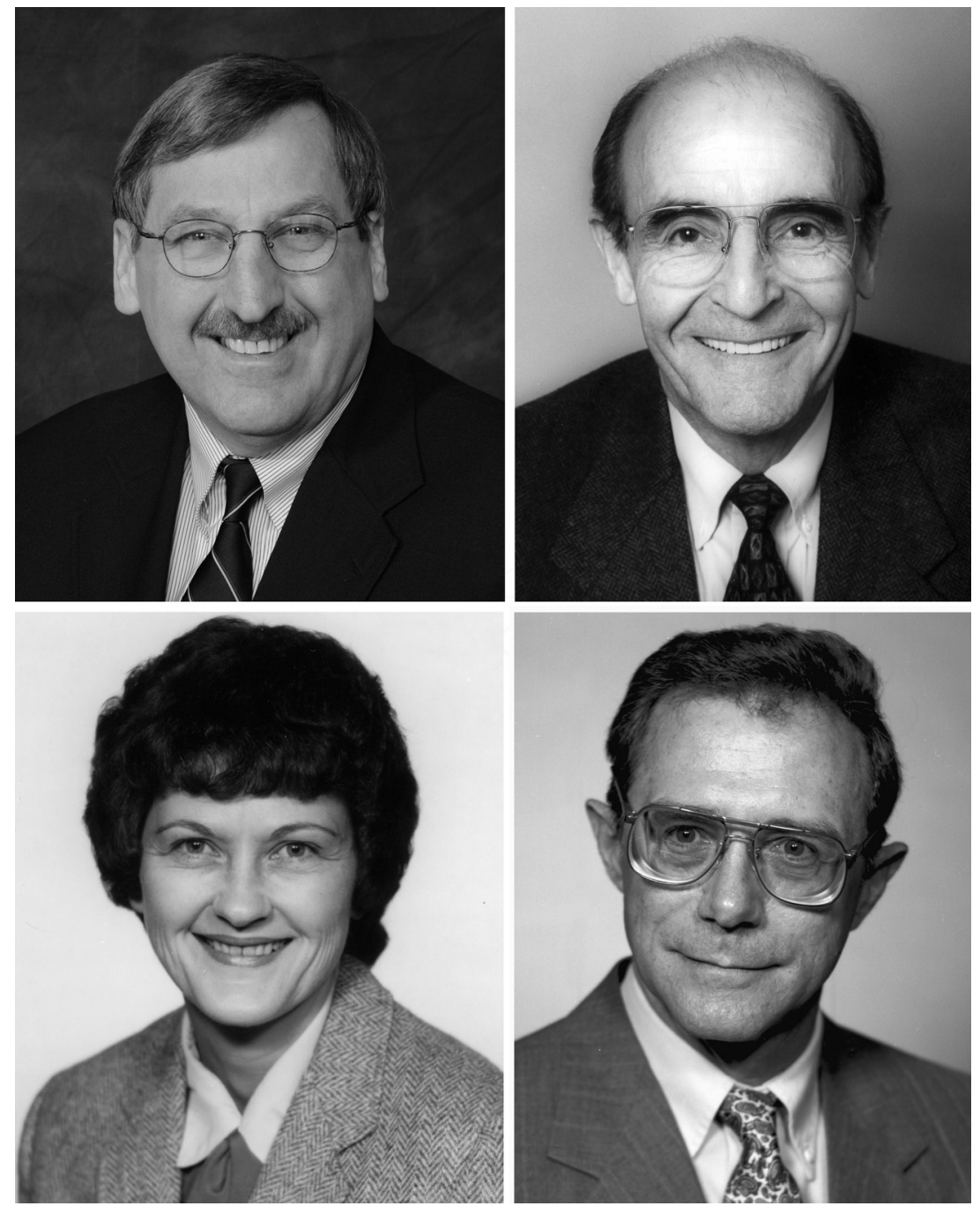

Fig. 2. NADC scientists in the ARS hall of fame. Clockwise from upper left: Ron Horst, William Mengeling, Harley Moon and Janice Miller.

available. His research and that of his collaborators identified and characterized fimbriae (pili) as specific and essential virulence factors enabling enterotoxigenic $E$. coli to attach to enterocytes in neonatal cattle, pigs, and lambs. Efficacious fimbrial-based vaccines providing passive protection against colibacillosis for neonatal farm animals evolved from this research (Moon and Bunn, 1993), and remain a prime example of a technology successfully transferred from USDA-ARS laboratories to commercial production.

Dr. Moon (Fig. 2) published the first detailed description of enteropathogenic E. coli (EPEC) attachment to pig and rabbit intestinal epithelial cells, an attachment associated with exfoliation of epithelial cell microvilli (Moon et al., 1983). He originated and popularized the term "attaching and effacing" ( $\mathrm{AE}$ ) for the distinct appearance of this colonization mechanism first described by researchers at Oklahoma State University (Staley et al., 1969). The intestinal cells form pedestals or 'cups' into which the $E$. coli bacteria nestle. The AE colonization mechanism is typical of colonization of cattle intestines by strains of
E. coli which are foodborne pathogens of humans, e.g. E. coli strain 0157:H7. Dr. Moon's foundational observations opened new fields of research with a focus on molecular pathogenesis, immunology, and genetics of AE E. coli and new strategies for controlling $E$. coli foodborne infections (Sharma et al., 2011).

Not only at the NADC, but around the world, Dr. Moon was a role model veterinary scientist for several generations of scientists investigating microbial-host interactions in pathogenesis. With nearly 200 highly cited publications, he remains one of the most productive researchers to have worked at the NADC. Dr. Moon served as NADC's fourth director from 1988 to 1995 . He was elected to the U.S. National Academy of Sciences in 1991 and inducted into the ARS Hall of Fame in 2000.

\section{Metabolic disease: milk fever and vitamin $D$ research}

NADC's research portfolio has historically consisted of a balance between infectious and metabolic diseases. The 
most notable metabolic disease research investigated metabolic diseases of cattle and was led by Drs. Ronald Horst, Jesse Goff and Tim Reinhardt. This group is renowned internationally for their work on milk fever in dairy cattle and vitamin D metabolism. Milk fever results from a metabolic imbalance of calcium that occurs at the onset of calving and affects $\sim 6 \%$ of cows at a cost to the dairy industry of $\$ 250$ million annually. In milk fever cases, the animal is unable to mobilize enough calcium stores to compensate for losses through milk secretion and thus becomes hypocalcemic and exhibits clinical symptoms that include loss of appetite, lateral recumbency, tetany and eventual death if left untreated. Secondary diseases are a common sequelae to milk fever and include ketosis, displaced abomasum and mastitis. Dr. Horst (Fig. 2) and co-workers' research led to the discovery that milk fever was caused by high levels of dietary cations $\left(\mathrm{K}^{+}, \mathrm{Na}^{+}, \mathrm{Ca}^{2+}\right.$, and $\left.\mathrm{Mg}^{2+}\right)$, which resulted in a metabolic alkalosis that prevented the action of parathyroid hormone in the periparturient cow. This lack of parathyroid activity resulted in a loss of calcium regulating mechanisms and a life-threatening drop in blood calcium. These studies broke with conventional veterinary textbook dogma at the time-that high dietary calcium was the cause of milk fever. They found that the simple addition of chloride ion to feed would alleviate this metabolic alkalosis and overcome the blockade to parathyroid function imposed by excessive dietary potassium and thereby dramatically reduce the incidence of milk fever (Goff and Horst, 1998). This research has resulted in the commercialization of the product SoyChlor, a feed additive for dairy cattle that is still on the market and remains effective against the condition.

Dr. Horst's team also elucidated the processes of activation and deactivation of fat-soluble vitamins, especially vitamin D. Drs. Reinhardt and Horst developed a quick and easy assay to measure 1,25-dihydroxyvitamin $\mathrm{D}$ that remains NADC's most cited article to date (Reinhardt et al., 1984), and has also been applied to vitamin D studies in human medicine to enhance the understanding of renal failure, osteoporosis and neoplasia (Koszewski et al., 1999; Salusky et al., 1990; Slatopolsky et al., 1984). More recently, Drs. John Lippolis and Reinhardt discovered that vitamin D profoundly affects innate immune function in cattle and that when co-administered with antibiotics into the mammary gland can augment and enhance the efficacy of antibiotics in treating chronic mastitis (Lippolis et al., 2011; Nelson et al., 2010). Dr. Horst authored or co-authored over 330 peer-reviewed publications, the most of any NADC scientist. He received the Presidential Rank Award of Meritorious Senior Professional, and was inducted into the ARS Hall of Fame in 2010.

\section{Discovery and eradication of bovine leukocyte adhesion deficiency}

A team of scientists led by Dr. Marcus E. Kehrli, Jr., from NADC made a serendipitous discovery that led to the virtual elimination of an autosomal recessive lethal condition in Holstein dairy cattle around the world
(Shuster et al., 1992b). This was the result of an observation on a control calf in an unrelated experiment in 1989 with a syndrome reminiscent of human leukocyte adhesion deficiency. The occurrence of this condition led to experiments describing the molecular nature of what was later confirmed to be a $\beta 2$-integrin adhesion molecule deficiency on bovine leukocytes (Kehrli et al., 1992, 1990). This condition was defined as bovine leukocyte adhesion deficiency and the acronym BLAD was coined, which it is now known throughout the dairy industry. Research demonstrated this condition existed in U.S. Holstein cattle since 1941 and was likely around long before that time. Genetic testing is now routinely performed for this condition around the world. Around the time of its discovery, the prevalence of BLAD was slowly but steadily increasing. In 1991, BLAD was estimated to account for over 100,00 annual global calfhood deaths and its global prevalence was steadily increasing. The NADC-led research team defined the molecular basis for the function of the defective protein, and sequenced the normal and defective bovine CD18 alleles in Holstein cattle (Shuster et al., 1992a), and they developed a diagnostic PCR assay to genotype cattle on the basis of their CD18 alleles. It was immediately recognized that BLAD was carried by several of the most prominent sires and cows of the HolsteinFriesian breed over the previous 50 years. However, as a result of the patented diagnostic test, the number of young bulls enrolled as artificial insemination bull studs and carrying the defective allele causing BLAD has been virtually zero since 1993 . This research solved a major but previously unrecognized problem of considerable importance to dairy farmers and practitioners of veterinary medicine throughout the world.

\section{Innovation in laboratory biosafety/biosecurity}

Novel safety innovations designed and built at NADC include a finger pipetting device that eliminated the need for mouth pipetting of harmful substances (Songer et al., 1971), a portable ethylene oxide chamber used for sterilizing heat-labile materials (Songer and Mathis, 1969), and an ultra filter for germ free animal isolation units (Songer et al., 1978, 1974). Furthermore, NADC scientists evaluated the effectiveness of standard safety practices. For example, the effectiveness of decontaminating boots using various methods was first assessed at NADC (Braymen et al., 1974). This study found that footbaths were an ineffective method at removing microorganisms on the surface of footwear. The results of this study were later used by the shrimp farming industry to stop the practice of footbaths (Moss, 2002), which may actually foster the propagation of microorganisms. Also extensive testing of harmful disinfectants such as formaldehyde and phenol was conducted and reported (Braymen and Songer, 1971; Songer et al., 1972). These results were used as guidelines for the decontamination of Bacillius anthracis at the U.S. Post Office in Landover, MD (Canter et al., 2005). More recently, NADC facilities have hosted several international biosafety conferences, including a gathering of high-containment laboratory directors from around the world. 


\section{The Ames Modernization Project and NADC's current research}

Plans to modernize and replace the NADC and USDA APHIS animal health facilities co-located on the USDA Ames campus were initiated in the mid-1990s. These modernization plans came to be known as the 'USDA Ames Modernization Project' and ultimately represented the largest construction project ever undertaken in USDA history. The USDA Ames Modernization Project was strongly supported by a broad-based coalition of animal production and health stakeholders who successfully influenced bipartisan Congressional and Presidential support to win approval for funding totaling $\$ 467 \mathrm{M}$. Design of the new facilities commenced in 2001 and construction was completed in 2009. The newly constructed facilities are among the most extensive and advanced high-containment large animal disease research facilities in the world; there are fewer than five comparable facilities worldwide. These state of the art facilities combined with concurrent advances in the scientific fields of genomics, microbial ecology, immunology, and systems biology are converging to create an unprecedented opportunity for NADC scientists to build upon their strong tradition of leadership in animal health research and continue to define innovation and global leadership in animal health and food safety research.

Dr. Kurt Zuelke became NADC's seventh Director in 2006. To coincide with the transition into the new facilities in 2009, the NADC leadership team developed an ambitious five-year business plan that leveraged the new facilities with ongoing scientific advances in genomics and the life sciences to address the nation's most pressing animal health problems. NADC is now focused around four strategic research themes that include ruminant diseases and immunology; emerging diseases (most notably viral and prion diseases); zoonotic diseases in wildlife and livestock species; and, microbial ecology in food safety and animal health. Although the core of animal health research continues to revolve around basic disease pathogenesis and transmission research, NADC researchers across all four of these strategic themes are pioneering early development and integration of high-throughput genomics and systems biology platforms to yield new and exciting breakthroughs in molecular-based diagnostic and disease intervention technologies.

\section{Genomics and metagenomic studies of agriculturally important species}

NADC is at the forefront of genomics, functional genomics and metagenomics research as it relates to infectious diseases and foodborne diseases of animals. Pasteurella multocida (May et al., 2001), Mycobacterium avium subsp. paratuberculosis (Li et al., 2005) and Brucella abortus (Halling et al., 2005) were among the first animal pathogens with genomes sequenced by researchers at NADC along with their collaborators. Microarrays constructed from pathogen sequence data have been produced using information from these genomes for transcriptomic and genomic diversity studies (Boyce et al., 2002, 2004; Marsh et al., 2006; Nicholson, 2007).
NADC is leveraging next-generation sequencing technologies by investing in the latest equipment and training researchers. With the rapidly developing power and lower cost of these technologies, metagenomic studies have become achievable. The first analysis of the avian intestinal metagenome in feed-deprived 3-week-old turkeys was accomplished using molecular techniques (Scupham, 2007). Data revealed a high percentage of Papillibacter in fasting turkeys, suggesting that these microbes may be specifically dividing in response to the environmental conditions.

Recently, NADC researchers and colleagues at Michigan State University applied metagenomics and quantitative PCR analyses to assess the impact of dietary antibiotics on the swine intestinal microbiome (Looft et al., 2012). These investigators demonstrated shifts in intestinal microbial populations, including elevated E. coli shedding, and increases in various metabolic and antibiotic resistance genes. The detection of bacteriophage carrying antibiotic resistance genes and likely capable of spreading the genes was also a discovery from these studies (Allen et al., 2011). Understanding the effects of antibiotics on intestinal microbes enhances our ability to monitor antibiotic use and discover antibiotic alternatives.

\section{Animal health research response to the 2009 H1N1 influenza $A$ virus outbreak}

In early 2009, a novel pandemic H1N1 influenzae A virus (H1N1pdm09) emerged in the human population in North America. This antigenically distinct H1N1 quickly spread in the human population, and the World Health Organization declared on June 11,2009 , that the outbreak had reached pandemic phase 6 . Although the sequences of the virus's eight gene segments were similar to those of corresponding genes from swine influenza A viruses from North America and Eurasia, no closely related ancestral influenza A viruses with this gene combination had been previously identified anywhere in the world. For the human population, the genome of the H1N1pdm09 virus contained novel forms of the matrix $(\mathrm{M})$ and neuraminidase (N1) genes that rendered this virus antigenically distinct from previously circulating strains (Garten et al., 2009). Therefore, the global human and swine populations were potentially immunologically naïve to this virus, and diagnostic tests available at the time could not differentiate it from other influenza virus strains. Within the first few weeks of the 2009 pandemic, a team of NADC scientists led by Drs. Amy Vincent, Kelly Lager and Kay Faaberg developed a differential diagnostic test for the pandemic virus in swine and conducted a series of high containment pathogenesis, transmission, and vaccine experiments with the H1N1 virus in swine (Vincent et al., 2010, 2009).

In response to this outbreak, a number of key countries immediately closed their borders to U.S. pork exports citing potential concerns that the H1N1 virus could affect the safety of U.S. pork products. The pathogenesis studies performed at NADC were the first to demonstrate that the tissue distribution of the 2009 pandemic virus was limited to tissues of the respiratory tract and that the virus was quickly cleared from infected pigs. These results confirmed 
that the H1N1 virus did not pose a food safety risk (Vincent et al., 2009) and that U.S. pork products were safe. This rapid research response enabled science-based decisions on the safety of U.S. pork and pork products during the early stages of the pandemic by providing data that was invaluable to U.S. and international pork producers. The U.S. government and the U.S. pork industry cited this research while engaging trading partners in a sciencebased conversation to maintain and re-open market access to over 27 countries that had banned or threatened to ban U.S. pork and pork products, costing the industry over $\$ 5.0 \mathrm{M}$ per day.

\section{Foodborne pathogens}

In response to the needs of producers and consumers, a major research paradigm shift occurred at the NADC in the late 1990s. Investigators who previously focused on controlling enteric bacterial pathogens of farm animals ( $E$. coli, Salmonella, and Brachyspira hyodysenteriae), adopted food safety research projects. They form the nucleus of the current Food Safety and Enteric Pathogens (FSEP) Unit. The FSEP Unit aims to reduce numbers of human foodborne pathogens and antibiotic resistant microbes in animals on the farm, before they get to humans. New chemical, biological, genetic, and immunological strategies are being explored, not only as control measures for human foodborne pathogens (and animal pathogens), but also as alternatives for reducing antibiotic use.

An early food safety intervention, from the labs of Drs. Tom Casey, Mark Rasmussen, and Iowa State University collaborator, Jacob Petrich, was the invention of a fluorescence detector for real time monitoring of animal carcasses for fecal contamination, a most important source of foodborne pathogens in meat products (Ashby et al., 2003). For this invention, these researchers were recognized by a national R\&D 100 award for a top 100 invention of the year, a 'da Vinci' Award from the State of Iowa, and a Superior Service Honor Award from the U.S. Secretary of Agriculture.

\section{Antibiotic resistance}

An important concern in animal agriculture today is the widespread use of antibiotics in animal feed. The extent of antibiotic resistance among members of the microbiome of animals has only begun to be appreciated in recent years; this results in clinical issues pertaining to treatment of animal diseases caused by resistant bacteria. Furthermore, it generates concern over the spread of antibiotic resistant bacteria, especially foodborne pathogens from animals to humans. But mechanistically, how does resistance to antibiotics spread? Studies at NADC have recently shown that antibiotic resistance genes are present in bacteriophage from swine fecal samples (Allen et al., 2011). These authors further demonstrate that the presence of antibiotics in animal feed induces latent phages to activate a lytic infection providing a means for antibiotic resistance gene transfer.

Selective pressure from frequent antibiotic use can drive both the spread and the evolution of antibiotic resistance genes. Dr. Arthur Andersen and collaborator Dr.
Dan Rockey were the first to demonstrate the presence of tetracycline resistance in swine strains of Chlamydia suis (Dugan et al., 2007, 2004; Lenart et al., 2001) and how readily new resistance is acquired through horizontal transfer and recombination events (Suchland et al., 2009). They showed the mosaic recombination of intraclass tetracycline resistance genes, which suggests the ease of transfer and intermingling of tet(C) alleles. Although the presence of antibiotic resistant chlamydia was initially controversial, tetracycline resistant strains are now widely accepted in the chlamydial field. NADC scientists also discovered the first example of interclass genetic recombination of tetracycline resistance genes, tet $(\mathrm{O})$ and tet $(\mathrm{W})$ alleles, in the strict anaerobe Megasphera elsdensii, a nonpathogen commensal bacterium, from the swine gut (Stanton et al., 2011).

\section{Conclusion and future perspectives}

While this review has focused on a select few highlights, in total NADC scientists have collectively published over 3000 research articles since the center opened in 1961. A selection of additional noteworthy accomplishments are listed in Table 1 . Today, the national need for innovative high impact animal health and food safety research at NADC and elsewhere has never been greater. Of the 1415 species of infectious organisms known to be pathogenic in humans, $61 \%$ are zoonotic, and more strikingly, $75 \%$ of newly emerging human pathogens are zoonotic (Taylor et al., 2001). The recent 2009 H1N1 pandemic influenza outbreak illustrates just how quickly a zoonotic infection can emerge and spread globally. With the global population estimated to grow to over 9 billion people by 2050 (Lee, 2011), there will continue to be an ever-increasing demand for new technologies to produce more food more efficiently while assuring food safety. Research solutions that enable cost-effective production of healthy livestock and poultry will be a critical component in a comprehensive strategy to assure global food security to meet the nutritional needs of the future population base. As future population pressures on the environment increase, the resulting loss of habitat will lead to closer proximity of wildlife and livestock populations and increase the likelihood of disease transmission among these animal populations and perhaps between animals and humans. Continued research using a combination of wildlife and domestic livestock animal models will be crucial to mitigating the potential impact of wildlife reservoirs of zoonotic diseases to human and animal health. The NADC research community is proud of the pioneering efforts of their scientists to date. Building upon the foundation laid down during the past 50 years with newly constructed facilities and cutting edge technologies, the NADC is well-positioned to lead the nation to meet the current and upcoming animal health and food safety challenges in the years to come.

\section{Acknowledgements}

We acknowledge the hard work of dedicated research scientists, technicians, animal caretakers, facility engineering 
Table 1

Additional significant research accomplishments at NADC.

\begin{tabular}{|c|c|c|c|}
\hline $\begin{array}{l}\text { Disease/disease agent/ } \\
\text { research target }\end{array}$ & Contribution & Researchers & Year(s) reported \\
\hline Bovine viral diarrhea virus & $\begin{array}{l}\text { Isolation of a strain of this virus later recognized } \\
\text { as the type strain of BVDV1. Is a component of } \\
\text { numerous vaccines. }\end{array}$ & DE Gutekunst, WA Malmquist & 1963 \\
\hline Leptospirosis & $\begin{array}{l}\text { Developed culture medium for the isolation and } \\
\text { propagation of leptospira bacteria. }\end{array}$ & $\begin{array}{l}\text { HC Ellinghausen Jr, WG } \\
\text { McCullough }\end{array}$ & 1965 \\
\hline Pink eye/Moraxella bovis & $\begin{array}{l}\text { Identification of Moraxella bovis as a cause of } \\
\text { "pink eye" in cattle. }\end{array}$ & $\begin{array}{l}\text { DE Hughes, GW Pugh Jr, } \\
\text { TJ McDonald }\end{array}$ & $1965-1968$ \\
\hline $\begin{array}{l}\text { Johne's disease/Mycobacterium } \\
\text { avium subsp. paratuberculosis }\end{array}$ & $\begin{array}{l}\text { Developed fecal culture techniques for early } \\
\text { detection of these slow growing mycobacteria. }\end{array}$ & RS Merkal, AB Larsen & $1962-1964$ \\
\hline Newcastle disease virus & $\begin{array}{l}\text { Development of a killed vaccine against the } \\
\text { Newcastle disease virus }\end{array}$ & $\begin{array}{l}\text { HD Stone, AE Richies, WA } \\
\text { Boney }\end{array}$ & 1969 \\
\hline Bovine leukemia virus (BLV) & $\begin{array}{l}\text { Demonstration that bovine leukemia is caused } \\
\text { by a virus. }\end{array}$ & JM Miller, C Olson & 1972 \\
\hline Bovine leukemia virus (BLV) & BLV first cultivated. & MJ Van der Maaten, JM Miller & 1974 \\
\hline Fowl cholera/Pasteurella multocida & $\begin{array}{l}\text { An improved bacterin developed that provided } \\
70 \% \text { cross protection from other strains of } \\
\text { Pasteurella. }\end{array}$ & $\begin{array}{l}\text { KA Brogden, KR Rhoades, } \\
\text { KL Heddleston }\end{array}$ & 1978 \\
\hline $\begin{array}{l}\text { Oxalate metabolism/Oxalobacter } \\
\text { formingenes }\end{array}$ & $\begin{array}{l}\text { Demonstration of importance of microbial } \\
\text { metabolism of oxalate in animal \& human } \\
\text { health }\end{array}$ & $\begin{array}{l}\text { MJ Allison, KA Dawson, NA } \\
\text { Cornick, AL Baetz }\end{array}$ & 1980-1990, 1996 \\
\hline $\begin{array}{l}\text { Salmonella typhimurium } \\
\text { infection of swine }\end{array}$ & $\begin{array}{l}\text { Identified the prefered colonization sites in } \\
\text { swine that are persistently infected with } \\
\text { Salmonella typhimurium. }\end{array}$ & RL Wood & 1989 \\
\hline Feline calicivirus & $\begin{array}{l}\text { First nucleotide sequence of calicivirus } \\
\text { 3'-terminal sub genomic RNA. }\end{array}$ & JD Neill & 1991 \\
\hline Brucellosis/Brucella abortus & $\begin{array}{l}\text { Demonstrated that vaccination of bison with } \\
\text { the RB51 strain induced abortion. }\end{array}$ & SC Olsen, MV Palmer & 1996 \\
\hline $\begin{array}{l}\text { Swine dysentery/Brachyspira } \\
\text { hyodysenteriae }\end{array}$ & $\begin{array}{l}\text { Discovery and genetic engineering application } \\
\text { of novel gene transfer mechanism (VSH-1) }\end{array}$ & TB Stanton, SB Humphrey & 1997-2008 \\
\hline $\begin{array}{l}\text { Bovine viral diarrhea virus and } \\
\text { border disease virus }\end{array}$ & $\begin{array}{l}\text { First nucleotide sequence of bovine diarrhea } \\
\text { virus } 2 \text { strain and border disease virus }\end{array}$ & JF Ridpath, SR Bolin & 1995,1997 \\
\hline Brucellosis/Brucella abortus & $\begin{array}{l}\text { Approval of RB51 for use in cattle for prevention } \\
\text { of Brucella abortus infection }\end{array}$ & $\begin{array}{l}\text { NF Cheville, SC Olsen, MV } \\
\text { Palmer }\end{array}$ & 1997 \\
\hline Shipping fever & $\begin{array}{l}\text { First genetically engineered live oral vaccine for } \\
\text { shipping fever. }\end{array}$ & RE Briggs, FM Tatum & 1999 \\
\hline $\begin{array}{l}\text { Bovine tuberculosis/ } \\
\text { Mycobacterium bovis }\end{array}$ & $\begin{array}{l}\text { Intratonsilar challenge model developed to } \\
\text { mimic natural M. bovis infection in white-tailed } \\
\text { deer. }\end{array}$ & $\begin{array}{l}\text { MV Palmer, DL Whipple, WR } \\
\text { Waters }\end{array}$ & 2000 \\
\hline Preharvest food safety & $\begin{array}{l}\text { Developed a fecal contamination detector for } \\
\text { animal carcasses using light sources of different } \\
\text { wavelengths }\end{array}$ & TA Casey, MA Rasmussen & 2003 \\
\hline $\begin{array}{l}\text { Bovine tuberculosis/ } \\
\text { Mycobacterium bovis }\end{array}$ & $\begin{array}{l}\text { A calf aerosol challenge model developed for } M \text {. } \\
\text { boivs }\end{array}$ & MV Palmer, WR Waters & 2003 \\
\hline Johne's disease/Mycobacterium & Demonstrated that milk pasteurization & JR Stabel & 2004 \\
\hline
\end{tabular}

effectively kills Mycobacterium avium subsp. paratuberculosis

Scrapie, Chronic wasting disease (CWD) and transmissible mink encephalopathy

First to complete interspecies transmission studies into cattle. Found that cattle were resistant to scrapie and CWD.
AN Hamir, RA Kunkle, JA Richt, JM Miller, RC Cutlip 
Table 1 (Continued)

\begin{tabular}{ll}
\hline $\begin{array}{l}\text { Disease/disease agent/ Contribution } \\
\text { research target }\end{array}$ & Researchers \\
\hline
\end{tabular}

BSE/Prion

Adenovirus

Bovine tuberculosis/

Mycobacterium bovis

Johne's disease/Mycobacterium

avium subsp. paratuberculosis
Confirmed that the E211 $\mathrm{K}$ polymorphism discovered at NADC in 2008 was a germline polymorphism indicating certain rare, atypical BSE cases may be heritable.
EM Nicholson, BW Brunelle, JA

2008

Richt, ME Kehrli, JJ Greenlee

HD Lehmkuhl, LA Hobbs

2008

adenovirus to determine serotype/species.

Developed a rapid serologic test for cervids that

USAHA recommended using in the TB

erradication program.

Isolation of the first $M$. avium subspecies paratuberculosis-specific monoclonal antibody.
WR Waters, MV Palmer

2011

JP Bannantine, JR Stabel
2011 and administrative support staff who have devoted their careers to ARS and the NADC. We also thank Janis K. Hansen for helpful discussions on NADC's early years. Mention of trade names or commercial products in this article is solely for the purpose of completing research objectives and does not imply recommendation or endorsement by the U.S. Department of Agriculture. USDA is an equal opportunity provider and employer.

\section{References}

Allen, H.K., Looft, T., Bayles, D.O., Humphrey, S., Levine, U.Y., Alt, D. Stanton, T.B., 2011. Antibiotics in feed induce prophages in Swine fecal microbiomes. MBio. 2

Ashby, K.D., Wen, J., Chowdhury, P., Casey, T.A., Rasmussen, M.A., Petrich, J.W., 2003. Fluorescence of dietary porphyrins as a basis for real-time detection of fecal contamination on meat. J. Agric. Food Chem. 51, 3502-3507.

Boyce, J.D., Wilkie, I., Harper, M., Paustian, M.L., Kapur, V., Adler, B., 2002 Genomic scale analysis of Pasteurella multocida gene expression during growth within the natural chicken host. Infect. Immun. 70, 6871-6879.

Boyce, J.D., Wilkie, I., Harper, M., Paustian, M.L., Kapur, V., Adler, B., 2004 Genomic-scale analysis of Pasteurella multocida gene expression during growth within liver tissue of chickens with fowl cholera. Microbes Infect. 6, 290-298.

Braymen, D.T., Songer, J.R., 1971. Phenol concentrations in the air from disinfection solutions. Appl. Microbiol. 22, 1166-1167.

Braymen, D.T., Songer, J.R., Sullivan, J.F., 1974. Effectiveness of footwear decontamination methods for preventing the spread of infectious agents. Lab. Anim. Sci. 24, 888-894.

Canter, D.A., Gunning, D., Rodgers, P., O'Connor, L., Traunero, C., Kempter, C.J., 2005. Remediation of Bacillus anthracis contamination in the U.S Department of Justice mail facility. Biosecur Bioterror 3, 119-127.

Cheville, N.F., 2009. Ultrastructural Pathology: The Comparative Basis of Disease, Second Edition. John Wiley \& Sons, 1000 p.

Clark, L.G., Kresse, J.I., Carbrey, E.A., Marshak, R.R., Hollister, C.J., 1961. Leptospirosis in cattle and wildlife on a Pennsylvania farm. J. Am. Vet Med. Assoc. 139, 889-891.

Dugan, J., Andersen, A.A., Rockey, D.D., 2007. Functional characterization of IScs605, an insertion element carried by tetracycline-resistant Chlamydia suis. Microbiology 153, 71-79.

Dugan, J., Rockey, D.D., Jones, L., Andersen, A.A., 2004. Tetracycline resistance in Chlamydia suis mediated by genomic islands inserted into the chlamydial inv-like gene. Antimicrob. Agents Chemother. 48, 3989-3995.

Garten, R.J., Davis, C.T., Russell, C.A., Shu, B., Lindstrom, S., Balish, A. Sessions, W.M., Xu, X., Skepner, E., Deyde, V., Okomo-Adhiambo, M. Gubareva, L., Barnes, J., Smith, C.B., Emery, S.L., Hillman, M.J., Rivailler, P., Smagala, J., de Graaf, M., Burke, D.F., Fouchier, R.A., Pappas, C., Alpuche-Aranda, C.M., Lopez-Gatell, H., Olivera, H., Lopez, I., Myers, C.A., Faix, D., Blair, P.J., Yu, C., Keene, K.M., Dotson Jr., P.D., Boxrud, D. Sambol, A.R., Abid, S.H., St George, K., Bannerman, T., Moore, A.L.,
Stringer, D.J., Blevins, P., Demmler-Harrison, G.J., Ginsberg, M., Kriner, P., Waterman, S., Smole, S., Guevara, H.F., Belongia, E.A., Clark, P.A. Beatrice, S.T., Donis, R., Katz, J., Finelli, L., Bridges, C.B., Shaw, M., Jernigan, D.B., Uyeki, T.M., Smith, D.J., Klimov, A.I., Cox, N.J., 2009. Antigenic and genetic characteristics of swine-origin 2009 A(H1N1) influenza viruses circulating in humans. Science 325, 197-201.

Goff, J.P., Horst, R.L., 1998. Use of hydrochloric acid as a source of anions for prevention of milk fever. J. Dairy Sci. 81, 2874-2880.

Halling, S.M., Peterson-Burch, B.D., Bricker, B.J., Zuerner, R.L., Qing, Z., Li, L.L., Kapur, V., Alt, D.P., Olsen, S.C., 2005. Completion of the genome sequence of Brucella abortus and comparison to the highly similar genomes of Brucella melitensis and Brucella suis. J. Bacteriol. 187, 2715-2726.

Hartskeerl, R.A., Collares-Pereira, M., Ellis, W.A., 2011. Emergence, control and re-emerging leptospirosis: dynamics of infection in the changing world. Clin Microbiol Infect 17, 494-501.

Kehrli Jr., M.E., Ackermann, M.R., Shuster, D.E., van der Maaten, M.J., Schmalstieg, F.C., Anderson, D.C., Hughes, B.J., 1992. Bovine leukocyte adhesion deficiency. Beta 2 integrin deficiency in young Holstein cattle. Am. J. Pathol. 140, 1489-1492.

Kehrli Jr., M.E., Schmalstieg, F.C., Anderson, D.C., Van der Maaten, M.J., Hughes, B.J., Ackermann, M.R., Wilhelmsen, C.L., Brown, G.B., Stevens, M.G., Whetstone, C.A., 1990. Molecular definition of the bovine granulocytopathy syndrome: identification of deficiency of the Mac-1 (CD11b/CD18) glycoprotein. Am. J. Vet. Res. 51, 1826-1836.

Kennedy, D., 2011. International efforts at paratuberculosis control. Vet. Clin. North Am. Food Anim. Pract. 27, 647-654, viii.

Koszewski, N.J., Reinhardt, T.A., Horst, R.L., 1999. Differential effects of 20 epi vitamin D analogs on the vitamin D receptor homodimer. J. Bone Miner. Res. 14, 509-517.

Lee, R., 2011. The outlook for population growth. Science 333, 569-573.

Lenart, J., Andersen, A.A., Rockey, D.D., 2001. Growth and development of tetracycline-resistant Chlamydia suis. Antimicrob. Agents Chemother. 45, 2198-2203.

Li, L., Bannantine, J.P., Zhang, Q., Amonsin, A., May, B.J., Alt, D., Banerji, N., Kanjilal, S., Kapur, V., 2005. The complete genome sequence of Mycobacterium avium subspecies paratuberculosis. Proc. Natl. Acad. Sci. U.S.A. 102, 12344-12349.

Lippolis, J.D., Reinhardt, T.A., Sacco, R.A., Nonnecke, B.J., Nelson, C.D., 2011. Treatment of an intramammary bacterial infection with 25-hydroxyvitamin $\mathrm{D}(3)$. PLoS ONE 6, e25479.

Looft, T., Johnson, T.A., Allen, H.K., Bayles, D.O., Alt, D.P., Stedtfeld, R.D., Sul, W.J., Stedtfeld, T.M., Chai, B., Cole, J.R., Hashsham, S.A., Tiedje, J.M. Stanton, T.B., 2012. In-feed antibiotic effects on the swine intestinal microbiome. Proc. Natl. Acad. Sci. U.S.A. 109, 1691-1696.

Marsh, I.B., Bannantine, J.P., Paustian, M.L., Tizard, M.L., Kapur, V., Whittington, R.J., 2006. Genomic comparison of Mycobacterium avium subsp. paratuberculosis sheep and cattle strains by microarray hybridization. J. Bacteriol. 188, 2290-2293.

May, B.J., Zhang, Q., Li, L.L., Paustian, M.L., Whittam, T.S., Kapur, V., 2001. Complete genomic sequence of Pasteurella multocida, Pm70. Proc. Natl. Acad. Sci. U.S.A. 98, 3460-3465.

Mengeling, W.L., 1972. Porcine parvovirus: properties and prevalence of a strain isolated in the United States. Am. J. Vet. Res. 33, 2239-2248.

Mengeling, W.L., Brown, T.T., Paul, P.S., Gutekunst, D.E., 1979. Efficacy of an inactivated virus vaccine for prevention of porcine parvovirusinduced reproductive failure. Am. J. Vet. Res. 40, 204-207. 
Mengeling, W.L., Lager, K.M., Vorwald, A.C., 1999a. Safety and efficacy of vaccination of pregnant gilts against porcine reproductive and respiratory syndrome. Am. J. Vet. Res. 60, 796-801.

Mengeling, W.L., Lager, K.M., Wesley, R.D., Clouser, D.F., Vorwald, A.C., Roof, M.B., 1999b. Diagnostic implications of concurrent inoculation with attenuated and virulent strains of porcine reproductive and respiratory syndrome virus. Am. J. Vet. Res. 60, 119-122.

Mengeling, W.L., Pirtle, E.C., Torrey, J.P., 1963. Identification of Hog Cholera Viral Antigen by Immunofluorescence. Application as a Diagnostic and Assay Method. Can. J. Comp. Med. Vet. Sci. 27, 249-252.

Mengeling, W.L., Vorwald, A.C., Lager, K.M., Clouser, D.F., Wesley, R.D., 1999c. Identification and clinical assessment of suspected vaccinerelated field strains of porcine reproductive and respiratory syndrome virus. Am. J. Vet. Res. 60, 334-340.

Miller, J.M., Jenny, A.L., Payeur, J.B., 2002. Polymerase chain reaction detection of Mycobacterium tuberculosis complex and Mycobacterium avium organisms in formalin-fixed tissues from culture-negative ruminants. Vet. Microbiol. 87, 15-23.

Miller, J.M., Jenny, A.L., Taylor, W.D., Marsh, R.F., Rubenstein, R., Race, R.E., 1993. Immunohistochemical detection of prion protein in sheep with scrapie. J. Vet. Diagn. Invest. 5, 309-316.

Miller, J.M., Miller, L.D., Olson, C., Gillette, K.G., 1969. Virus-like particles in phytohemagglutinin-stimulated lymphocyte cultures with reference to bovine lymphosarcoma. J. Natl. Cancer Inst. 43, 1297-1305.

Miller, J.M., Van Der Maaten, M.J., 1977. Use of glycoprotein antigen in the immunodiffusion test for bovine leukemia virus antibodies. Eur. J. Cancer 13, 1369-1375.

Miller, J.M., Whetstone, C.A., Bello, L.J., Lawrence, W.C., 1991. Determination of ability of a thymidine kinase-negative deletion mutant of bovine herpesvirus- 1 to cause abortion in cattle. Am. J. Vet. Res. 52, 1038-1043.

Moon, H.W., Bunn, T.O., 1993. Vaccines for preventing enterotoxigenic Escherichia coli infections in farm animals. Vaccine 11, 200-213.

Moon, H.W., Whipp, S.C., Argenzio, R.A., Levine, M.M., Giannella, R.A., 1983. Attaching and effacing activities of rabbit and human enteropathogenic Escherichia coli in pig and rabbit intestines. Infect. Immun. 41, 1340-1351.

Moss, S.M., 2002. Marine shrimp farming in the western hemisphere: past problems, present solutions, and future visions. Rev. Fisheries Sci. 10, 601-620.

Nelson, C.D., Reinhardt, T.A., Thacker, T.C., Beitz, D.C., Lippolis, J.D., 2010. Modulation of the bovine innate immune response by production of 1alpha,25-dihydroxyvitamin D(3) in bovine monocytes. J. Dairy Sci. 93, 1041-1049.

Nicholson, T.L., 2007. Construction and validation of a first-generation Bordetella bronchiseptica long-oligonucleotide microarray by transcriptional profiling the Bvg regulon. BMC Genomics 8, 220.

Pappas, G., 2010. The changing Brucella ecology: novel reservoirs, new threats. Int. J. Antimicrob. Agents 36 (Suppl. (1)) S8-S11.

Paul, P.S., Mengeling, W.L., 1984. Oronasal and intramuscular vaccination of swine with a modified live porcine parvovirus vaccine: multiplication and transmission of the vaccine virus. Am. J. Vet. Res. 45, 2481-2485.

Paul, P.S., Mengeling, W.L., 1986. Vaccination of swine with an inactivated porcine parvovirus vaccine in the presence of passive immunity. J. Am. Vet. Med. Assoc. 188, 410-413.

Reinhardt, T.A., Horst, R.L., Orf, J.W., Hollis, B.W., 1984. A microassay for 1,25-dihydroxyvitamin D not requiring high performance liquid chromatography: application to clinical studies. J. Clin. Endocrinol. Metab. 58, 91-98.
Salusky, I.B., Goodman, W.G., Horst, R., Segre, G.V., Kim, L., Norris, K.C., Adams, J.S., Holloway, M., Fine, R.N., Coburn, J.W., 1990. Pharmacokinetics of calcitriol in continuous ambulatory and cycling peritoneal dialysis patients. Am. J. Kidney Dis. 16, 126-132.

Scupham, A.J., 2007. Examination of the microbial ecology of the avian intestine in vivo using bromodeoxyuridine. Environ. Microbiol. 9, 1801-1809.

Sharma, V.K., Dean-Nystrom, E.A., Casey, T.A., 2011. Evaluation of hha and hha sepB mutant strains of Escherichia coli 0157:H7 as bacterins for reducing E. coli O157:H7 shedding in cattle. Vaccine 29, 5078-5086.

Shuster, D.E., Bosworth, B.T., Kehrli Jr., M.E., 1992a. Sequence of the bovine CD18-encoding cDNA: comparison with the human and murine glycoproteins. Gene 114, 267-271.

Shuster, D.E., Kehrli Jr., M.E., Ackermann, M.R., Gilbert, R.O., 1992b. Identification and prevalence of a genetic defect that causes leukocyte adhesion deficiency in Holstein cattle. Proc. Natl. Acad. Sci. U.S.A. 89, 9225-9229.

Slatopolsky, E., Weerts, C., Thielan, J., Horst, R., Harter, H., Martin, K.J., 1984. Marked suppression of secondary hyperparathyroidism by intravenous administration of 1,25-dihydroxy-cholecalciferol in uremic patients. J. Clin. Invest. 74, 2136-2143.

Songer, J.R., Braymen, D.T., Mathis, R.G., Monroe, J.W., 1972. The practical use of formaldehyde vapor for disinfection. Health Lab Sci. 9, 46-55.

Songer, J.R., Mathis, R.G., 1969. Portable ethylene oxide sterilization chamber. Appl. Microbiol. 17, 671-675.

Songer, J.R., Mathis, R.G., Nelson, T.P., 1978. Autoclavable ultrahighefficiency filter for use with flexible film germfree animal isolators. Lab. Anim. Sci. 28, 757-759.

Songer, J.R., Matthews, P.J., Braymen, D.T., Dennis, D.E., 1974. An ultrahigh-efficiency filter for use with flexible film germfree animal isolators. Lab. Anim. Sci. 24, 943-945.

Songer, J.R., Sullivan, J.F., Monroe, J.W., 1971. Safe, convenient pipetting device. Appl. Microbiol. 21, 1097-1098.

Staley, T.E., Jones, E.W., Corley, L.D., 1969. Attachment and penetration of Escherichia coli into intestinal epithelium of the ileum in newborn pigs. Am. J. Pathol. 56, 371-392.

Stanton, T.B., Humphrey, S.B., Stoffregen, W.C., 2011. Chlortetracyclineresistant intestinal bacteria in organically raised and feral Swine. Appl. Environ. Microbiol. 77, 7167-7170.

Suchland, R.J.Sandoz, K.M., Jeffrey, B.M., Stamm, W.E., Rockey, D.D., 2009 Horizontal transfer of tetracycline resistance among Chlamydia spp. in vitro. Antimicrob. Agents Chemother. 53, 4604-4611.

Taylor, L.H., Latham, S.M., Woolhouse, M.E., 2001. Risk factors for human disease emergence. Philos. Trans. R. Soc. Lond. B: Biol. Sci. 356, 983-989.

U.S. Department of Agriculture, A.R.S., 1978. Hog Cholera Eradicated. Agricultural Research Magazine, March 8.

Vincent, A.L., Lager, K.M., Faaberg, K.S., Harland, M., Zanella, E.L., CiacciZanella, J.R., Kehrli Jr., M.E., Janke, B.H., Klimov, A., 2010. Experimental inoculation of pigs with pandemic H1N1 2009 virus and HI crossreactivity with contemporary swine influenza virus antisera. Influenza Other Respi Viruses 4, 53-60.

Vincent, A.L., Lager, K.M., Harland, M., Lorusso, A., Zanella, E., CiacciZanella, J.R., Kehrli, M.E., Klimov, A., 2009. Absence of 2009 pandemic H1N1 influenza A virus in fresh pork. PLoS ONE 4, e8367.

Whetstone, C.A., VanDerMaaten, M.J., Miller, J.M., 1991. A western blot assay for the detection of antibodies to bovine immunodeficiency-like virus in experimentally inoculated cattle, sheep, and goats. Arch. Virol. 116, 119-131.

White, T.G., Shuman, R.D., 1961. Fermentation reactions of Erysipelothrix rhusiopathiae. J. Bacteriol. 82, 595-599. 